Please do not remove this page

RMIT

UNIVERSITY

\title{
Migrant aged-care workers in Australia: do they have poorer-quality jobs than their locally born counterparts?
}

Charlesworth, Sara; Isherwood, Linda

https://researchrepository.rmit.edu.au/esploro/outputs/9922036737801341/filesAndLinks?institution=61RMIT_INST\&index=null

Charlesworth, S., \& Isherwood, L. (2020). Migrant aged-care workers in Australia: do they have poorer-quality jobs than their locally born counterparts? Ageing \& Society, 41(12), 2702-2722. https://doi.org/10.1017/S0144686X20000525

Document Version: Accepted Manuscript

Published Version: https://doi.org/10.1017/S0144686X20000525

Repository homepage: https://researchrepository.rmit.edu.au CC BY-NC-ND V4.0

(c) The Author(s), 2020. Published by Cambridge University Press

Downloaded On 2023/04/27 00:31:00 +1000 


\title{
Pre print of:
}

Charlesworth, S. \& Isherwood, L. (2020) Migrant aged-care workers in Australia: do they have poorer-quality jobs than their locally born counterparts? Ageing \& Society, 1 - 21. DOI 0144686X20000525

\begin{abstract}
Migrants make up a significant and growing proportion of the aged care workforce in Australia. Using data from the 2016 National Aged Care Workforce Census and Survey we investigate employment conditions for Australian-born and overseas-born frontline workers working in residential and home-based aged care, focusing on two key poor job quality indicators. We find that migrant home care workers from non-English speaking background (NESB) countries are the most likely to be employed on a casual basis and to report hours-related underemployment. Migrant residential care workers from English speaking background (ESB) countries are more likely to be casual while NESB migrants are more likely to be underemployed. Controlling for a range of employment and sociodemographic characteristics, we find that being an NESB migrant is significantly associated with both casual status and underemployment. Generally, while this association lessens with years spent in Australia, exposure to casual employment is amplified over time for NESB migrants in the residential sector. Holding a temporary visa increased the likelihood of casual employment for residential care workers and underemployment for home care workers. Working for a for-profit employer was also associated with poorer job quality. Further policy shifts in Australia towards temporary migration and increased marketisation of aged care may impact on the working conditions of migrant aged care workers.
\end{abstract}

\section{Key words}

Aged care workers, Australia, migrant status, non-English speaking background, job quality, contract status, underemployment, employment regulation

\section{Introduction}

The literature on migrant care work in developed economies emphasises an international pattern of increasing reliance on both new and existing populations of migrants in long term care to provide a 
source of low paid labour as a response to the growing demand for care workers (Simonazzi 2009; Michel and Peng 2017). As in other OECD countries with aging populations, in Australia there has also been a significant policy focus on meeting projected demands for an increased aged care workforce. The supply of, and demand for aged care workers has been the subject of several government inquiries over the last decade with recommended workforce strategies addressing attraction and retention issues, current and future skill demands, and pay and working conditions (Productivity Commission 2011; Tune 2017; Senate Community Affairs Reference Committee 2017; Pollaers 2018). Yet while there have been some employer calls for increased migration to help meet current and future demand (Adamson et al. 2017), none of these government inquiries were charged with investigating nor made any recommendations about migration strategies to support an increased aged care workforce.

This lack of attention to migration in the Australian aged care workforce context is perhaps surprising, given a growing proportion of frontline aged care workers are migrants. Australian Bureau of Statistics (ABS) Census data indicates that of personal care assistants, the main occupation in residential aged care, the proportion of overseas-born workers, grew from 43.7 percent in 2011 to 50.2 per cent in 2016. Of aged and disabled workers, the main occupation in home-based care, the proportion of migrants grew from 33.0 percent in 2011 to 37.0 per cent in 2016. The 2016 profile of these two occupations in Table 1 suggests a highly feminised workforce with a higher proportion of male workers among the overseas-born than in the Australian-born population of aged care workers. What is striking is the relatively large proportion of migrant workers who were born outside the main English-speaking background (ESB) countries, described here as non-English speaking background (NESB) migrants.

Insert Table 1 about here

Simonazzi suggests there are two main groups of migrants who work in paid care: those who have migrated to engage in care work and those who have 'ended up' in care work because this was the only work available (2009: 225). Unlike many other developed countries, in Australia there have 
been no 'front-door' visa pathways for aged care workers, whose work is deemed 'low-skilled' (Howe, Charlesworth and Brennan 2019). The Australian situation has been described as 'migrants working in aged care' rather than 'migrant aged care workers' as historically most migrant aged care workers have been long-standing migrants with permanent residence (Howe 2009: 388). However, over the last decade much has changed in Australia's migration and aged care regimes. Despite a long history of permanent migration mainly from the United Kingdom and other European countries, there has been rapid shifts both towards migration from NESB countries and towards temporary migration as the norm (Mares 2016). As in Table 1, a growing proportion of the frontline aged care workforce is made up of migrant workers from NESB countries. There is also evidence of an increasing number of newer migrants working in the care sector who arrived on temporary visas (Eastman et al. 2018a).

In this paper we investigate differences in migrant status for both home care workers and personal care workers against two key poor job quality indicators: casual status and underemployment. These workers are the non-nursing, personal care workers in long-term care (OECD 2019). In Australia, they make up 84 per cent of direct care workers in home-based services and 70 per cent in residential services (Mavromaras et al. 2017). While their tasks can vary, home care and personal care workers provide 'hands-on' care and support with the activities of daily living to increasingly frail service users with complex care needs, often in conditions of understaffing and a lack of time to care (Meagher et al. 2019).

We use data from the 2016 National Aged Care Workforce Census and Survey (NACWCS) to focus on differences between Australian-born workers, those born in ESB countries and those born in NESB countries. Our rationale for doing so lies in international evidence outlined below that points to differences in the working conditions between diverse groups of migrants, including in care work, that suggests in Australia NESB migrant workers may also experience some significant disadvantages in employment. Our focus on casual contract status and underemployment draws on employment relations and job quality literature that suggests these dimensions of poor job quality can contribute to employment precarity. 
In the next section we set out the framings for our analysis drawing on a brief review of literature that highlights how regimes of care, employment and migration shape conditions for migrant care workers. We also outline relevant scholarship on the dimensions of job quality used in our analysis. After outlining our methods, we describe key findings of our analyses of the NACWCS, focusing on casual status and underemployment. In particular we explore the extent to which any disadvantage for migrant aged care workers is 'washed out' over time both in terms of years spent in Australia and with the current employer.

\section{Migrant Care Workers and Employment Conditions}

\section{Care, migration and employment regimes in international context}

A number of scholars have drawn attention to the intersecting regimes of care, employment and migration in understanding how the conditions of work for migrant care workers are produced (Williams 2012; van Hooren 2012; Bauer and Österle 2013). In many instances, the convergence of these policy and regulation regimes has produced a precarious labour market for migrant workers, predominantly women. In Europe and North America, migrant status is seen to intersect with and contribute to the gendered precarity of care work, particularly for temporary and undocumented migrants (Simonazzi 2009; Shutes and Chiatti 2012; Michel and Peng 2017). There has been far less focus, however, on the experience of permanent migrants, which remains the predominant grouping of migrant workers in the Australian aged care workforce.

There is agreement in the international literature that migrant workers are significantly disadvantaged in the long-term care labour market. There is evidence of disadvantage for foreign born care workers throughout OECD countries including 'shorter contracts, more irregular hours, broken shifts, lower pay and in lower classified functions than non-migrant care workers', and in the UK, that migrant workers are more likely to earn less than the minimum wage, and more likely to be located in the lower paid private sector (Columbo et al. 2011: 175-176). 
groups of migrant workers based on their country of origin. For example, in the European context, non-EU nationals generally have been found to have worse labour market outcomes than EU-migrant workers (Peracchi and Depalo 2006). In the Netherlands 'non-western' migrants appear to have poorer contracts and working conditions compared with migrants from western countries (Eurofound 2007: 47). A number of Australian studies also provide evidence that migrant workers from NESB countries experience significant disadvantages in employment (Ho and Alcorso 2004; Boese et al. 2013; Colic-Peisker 2011).

In a qualitative Irish study, the experiences of migrant care workers were found to differ significantly according to their country of origin with non-Irish European carers experiencing the least disadvantage (Doyle and Timonen 2009). Differences between locally born workers and migrant care workers who come from countries outside the dominant local language or ethnic group have also been identified in England (Stevens, Hussein and Manthorpe 2012) and in Sweden (Jönson and Giertz 2013). This latter study found the experiences of Nordic-born migrant care workers were similar to Swedish-born care workers. However non-Nordic-born migrant workers were more likely to report they were in temporary employment, had a higher workload and less influence over their working conditions than Nordic-born workers (Jönson and Giertz 2013). Though they do not specifically consider migrant status, in their analysis of pay variance in the social care sector in the UK, Hussein and Manthorpe (2014) found that black and minority ethnic groups earn significantly less as professional and direct care workers.

\section{Job quality and care labour in Australian context}

Work conditions are directly linked with the quality of aged care services. The settings necessary to provide for effective care relationships between frontline workers and service users require a stable workforce and decent working conditions (Armstrong 2016). In Australia there is significant evidence that aged care workers are concerned about low pay rates and poor working conditions including not having enough time to care (Meagher et al. 2019; Mavromaras et al. 2017). Poor job quality directly impacts not only the continuity and consistency of formal care for older 
Australians, it also presents a major barrier to attraction and retention of aged care workers into the future (Senate Community Affairs Reference Committee 2017).

Our specific focus in this paper on contract status and having sufficient hours of work in the current job draws broadly on the job quality literature which assesses job quality from the perspective of the worker (Burchell et al. 2014; Green 2009; Eurofound 2017). The job quality approach we draw in here focuses on more intrinsic or 'objective' features of the job such as wages, contract status and working time in terms of the quantum, scheduling and autonomy over hours (Charlesworth et al. 2014). This approach recognises that job quality is also shaped by the socio-spatial location of the worker including gender and migration status (Noack and Vosko 2011).

In Australia, what is known as 'casual' employment is significant in international comparison and widely seen as a characteristic of precarious or vulnerable employment (Vosko, MacDonald and Campbell 2009). Casual employees currently comprise 25 per cent of all employees (ABS 2018a). They are excluded from many of minimum labour standards protections for permanent employees. While casual employees are entitled to an hourly rate of pay (with an additional 'loading' of 25 per cent in lieu of paid leave), they have no right to job security, to a regular schedule of hours or to secure employment with an employer (Campbell, Macdonald and Charlesworth 2019). Casual employees may be employed full-time or part-time.

In Australia the rate of time-related underemployment is focused in the main on part-time workers (both casual and permanent), who would prefer to work more hours and are available to work more hours in the reference week or in the four following weeks (ABS 2018b). This measure of under-employment includes both permanent and casual part-time workers. Underemployment is a significant and gendered problem in service industries linked to low weekly hours (Campbell, Macdonald and Charlesworth 2019). In general terms the fewer weekly hours part-time workers have, the more likely they are to want to work more hours (Wilkens and Lass 2018). 
Migrant status may also affect opportunities for securing quality jobs in the Australian aged care sector. A recent Australian study exploring the experiences of Asian migrant workers found that personal care assistants from Southern Asia were more likely to be employed on a casual contact while migrants from both South East Asia and Southern Asia were more likely than Australianborn workers and other migrants to be underemployed (Isherwood and King 2017). Building on this study, we focus on differences between Australian-born, ESB migrant and NESB migrant workers in respect of contract status and underemployment. We compare the experience of these three groups in each of the home care and personal care assistant occupations.

\section{The Study}

Data was gathered as part of the 2016 National Aged Care Workforce Census and Survey (NACWCS), the fourth NACWCS conducted by the National Institute of Labour Studies (NILS), on behalf of the Australian Department of Health. All aged care-funded residential and home care support providers were invited to participate. Each organisation was sent a package, which included the employer census, a set of surveys for direct care workers (stratified according to care places/client numbers), and information about how to distribute the surveys to obtain a random sample of workers (Mavromaras et al. 2017: 4-8). Responses were received from a total of 8,885 frontline workers in residential facilities (a response rate of 50 per cent) and 7,024 workers in community outlets (a response rate of 26 per cent) (Mavromaras et al. 2017: 8). This included 2,759 personal care assistants (PCAs) in residential facilities and 4,355 home care workers (HCWs) in community-based outlets. Sampling weights were constructed and applied to the worker survey data based on data on direct care worker numbers and occupational categories provided by residential and community-based outlets (for details on weighting approach used see Mavromaras et al. 2017: 168-172). This weighted data is used in the analyses reported in this paper.

There are some relevant limits to the 2016 NACWCS dataset. Firstly, while aged care employer reliance on agency and brokered employment is increasing (Mavromaras et al. 2017: 61, 127), the 
NACWCS includes only workers in a direct employment relationship with the facilities surveyed. Secondly, compared to the Census data in Table 1, the NACWCS sample has both a lower proportion of PCAs and HCWs born overseas and a lower proportion born in NESB countries (see Table 2 below). Finally, given our focus on underemployment, including its association to hours worked, the NACWCS data both overrepresents those PCAs working longer weekly hours and underrepresents those working shorter hours compared to 2016 Census data (Eastman et al. 2018b, 2018c).

\section{Analysis approach}

We draw on two key job quality indicators in the NACWCS employee survey. Firstly, contract status (measured by the question: 'What best describes your form of employment?' with options of casual, permanent (full or part-time); fixed term contract). Secondly, we examine underemployment as measured by a preference for more weekly hours of work in the current job (derived from the questions 'how many hours on average do you usually work each week in this job?' and 'how many hours (per week) would you like to work in this job?'). One solution to having insufficient hours of work is to pursue more hours in the current job. Another solution is to take on another job (Chalmers and Campbell 2008: 493). We therefore also consider the relationship of wanting more hours of work to hours of work in the current aged care job and also to multiple job-holding, which is strongly linked with underemployment (Wilkins and Lass 2018).

Analyses were initially conducted to compare the socio-demographic and occupational characteristics of workers depending on their country of birth. Significance testing (using chisquare analysis and analysis of variance) was carried out on differences in respect to each of these characteristics for Australian-born, ESB and NESB workers (where the Australian-born were the reference category). In respect to characteristics which only pertain to overseas-born workers such as years in Australia and residency status, ESB is the reference category. 
likelihood of casual employment and underemployment. Separate analyses were conducted for all HCWs and PCAs (including migrant and Australian-born workers) and for migrant workers (from ESB and NESB countries). A range of variables identified in previous research as having an association with employment conditions in the care sector were used as predictor variables in the analyses. These included socio- demographic variables (country of birth, sex, age, qualifications, financial dependants); job characteristics (tenure, usual paid hours, holding more than one job); and organisational characteristics (type of employer and size of agency). The logistic regression analyses were conducted using a direct entry method in IBM SPSS Statistics 24.0. This is because it could be assumed that over time workers would be more likely to move from casual to ongoing part time work and also to increase their hours of work and thus be less likely to want more hours of work or have more than one job.

We also explore the extent to which time spent in Australia washes out any disadvantage for ESB and NESB workers and the association, if any, temporary migrant status has with casual status and underemployment. Thus in the regression model for migrant workers only we have additional variables relating to migrant status - temporary residency, years in Australia and an interaction term for NESB status and years in Australia (NESB*Years in Australia). We also examine tenure with the current employer as another likely mitigating factor over time to any disadvantage identified. This is because it could be assumed that over time workers would be more likely to move from casual to ongoing part time work and also to increase their hours of work and thus be less likely to want more hours or work or have more than one job.

\section{Findings}

\section{Socio-demographic and occupational characteristics}

Table 2 sets out the key socio-demographic and employment characteristics of the HCW and the PCA respondents by country of birth. While our analyses of each group are separate, there are notable differences between the HCW and PCA respondents. On average, regardless of their country of birth, HCWs are older than PCAs and more likely to have a diploma or a 
degree. HCWs are also much more likely to be employed on casual contracts and to work fewer hours per week than PCAs. Perhaps as a consequence of this latter factor, HCWs are more likely to want more hours of work in their current job and to hold more than one job. Reflecting diverse aged care sector ownership profiles, HCWs and PCAS are differently distributed across types of employer, with government and not-for-profit employment more important for HCWs and for-profit employment more important for PCAs. Finally, HCWs are also more likely than PCAs to be based in smaller aged care organisations.

Insert Table 2 about here

Inter-group differences were found with regards to both socio-demographic and occupational characteristics. For example, while all groups of aged care workers are overwhelmingly female, NESB and ESB HCWs and NESB PCAs are significantly more likely to be male than Australianborn workers. HCWs and PCAs born in NESB countries were younger on average with those born in ESB countries older than their Australian-born counterparts.

NESB migrant workers (and especially when working as a PCA) had been in Australia for a shorter period than ESB migrants. A larger proportion of NESB than ESB workers hold a temporary visa, particularly in the case of PCAs. Another distinguishing feature of the NESB workforces is the high level of formal qualifications held, both relative to the Australian-born and to the ESB aged care workforce. NESB HCWs are more than four times as likely to hold a degree and NESB PCAs almost nine times as likely to hold a degree than those born in Australia.

NESB HCWs and ESB PCAs were more likely to be on a casual contract of employment than their Australian-born peers. Most of the HCWs and PCAs worked less than full-time. However workers from migrant backgrounds were more likely to work on a part-time basis. The lowest average paid weekly hours were worked by NESB HCWs (23.97 hours) while migrant PCAs worked slightly more hours on average than their Australian-born peers. 
more likely than their Australian-born peers to want more weekly hours of work than they currently had. Indeed well over half of NESB HCWs wanted more hours of work (55.7\%) While NESB PCAs were working almost one hour more a week on average than Australian-born PCAs, they were still significantly more likely to want more hours of work (49.6\%) than their Australian-born peers $(33.6 \%)$, while ESB PCAs were significantly less likely to do so (27.8\%).

Underemployment in frontline aged care work is also reflected in the high rate of multiple job holding. The rate for NESB HCWs and PCAs was much higher than that of their Australian-born or ESB born peers. While there are various assessments of multiple-job holding in Australia reflecting different methodologies, it is estimated that in 2016 around 8 per cent of workers held more than one job (Cassells et al. 2018: 18). The rate for NESB HCWs (21\%) is therefore more than two and a half times that national average.

Migrant HCWs were less likely than Australian-born HCWs to work for for-profit employers, while migrant PCAs were more likely to do so. What is striking is the relatively low level of government employment for migrant HCWs and particularly for NESB PCAs. Finally, migrant HCWs and NESB PCAs were less likely to work for small or medium sized employers.

\section{Selected employment conditions of migrant workers: Multivariate analyses}

In the following multivariate analyses, described above, we explore the factors associated with casual employment and underemployment separately for HCWs and PCAs, firstly for all workers (exploring the differences between ESB and non-ESB workers with their Australian-born peers) and then for our sample of migrant workers (identifying differences between ESB and NESB workers).

\section{Casual employment}

Table 3 sets out the factors associated with the likelihood of being on casual contract for both HCWs and PCAs. 
Insert Table 3 about here

One of the main factors associated with increased odds of HCWs being on a casual contract is being born in a NESB country. Controlling for all other factors in the model, NESB HCWs are 1.45 times more likely to be in casual employment than Australian-born workers. However, for ESB workers there is no significant difference in the likelihood of being on a casual contract.

When we look at outcomes for migrant HCWs, NESB workers are over five times more likely than their ESB counterparts to be casually employed. Time spent in the host country can lessen employment disadvantages for migrant workers. While overall, migrant HCWs are 0.99 times less likely to be on a casual contract with each additional year in Australia, this effect is stronger for NESB HCWs (OR 0.96) when compared to their ESB counterparts. Being a temporary resident was not found to significantly impact upon the likelihood of casual employment for migrant HCWs.

For migrant HCWs, in addition to NESB-status the likelihood of being on a casual contract was most strongly associated with working in a for-profit organisation (OR 18.15) and having financial dependants (OR 2.01).

For PCAs being an ESB migrant was significantly associated with being on a casual contract, with this group 1.18 times more likely to be casually employed than Australian-born workers. On the other hand, NESB PCAs are 0.70 times less likely to be casual than Australian-born workers. When comparing the effect of country of birth on the casual status of migrant workers only, we found that NESB PCAs are 0.40 times less likely to be casual than ESB PCAs. At the same time, while overall length of time in Australia reduces the likelihood of a migrant worker being on a casual contract (OR 0.98), NESB PCAs were 1.02 times more likely to be casual with each additional year in Australia when compared to ESB PCAs. For migrant PCAs, other factors most strongly associated with increased odds of being on a casual contract included being on a temporary visa (OR 1.98), wanting more hours in their current job (OR 1.95) or holding more than one job 


\section{Underemployment}

Table 4 sets out factors associated with the likelihood of wanting more hours of work in the current job for both HCWs and PCAs.

Table 4 about here

While NESB HCWs are almost twice as likely to be underemployed than Australian-born workers (OR 1.94), ESB HCWs are less likely to be underemployed than their Australian peers (OR 0.90).

For migrant HCWs, the strongest predictor associated with increased odds of underemployment is being born in a NESB country. NESB HCWs are around 13 times more likely to want more hours than ESB HCWs. Overall, the likelihood of underemployment for migrant HCWs increased slightly with each additional year living in Australia (OR 1.01). At the same time for NESB HCWs, years in Australia has a comparatively beneficial effect, with this group 0.94 times less likely to be underemployed with each additional year in Australia than ESB HCWs. Being on a temporary visa almost doubled the likelihood of a migrant $\mathrm{HCW}$ wanting more hours (OR 1.97). In addition, migrant HCWs working for a for-profit employer or in medium to very large organisations were around three times more likely to be underemployed.

For migrant PCAs, one of the key factors associated with increased odds of underemployment was being born in an NESB country. NESB PCAs were 2.57 times more likely to be underemployed than ESB PCAs. While, with each additional year in Australia migrant PCAs were 0.99 times less likely to be underemployed, no differences were found between NESB and ESB PCAs. Being a temporary resident also decreased the odds (OR 0.61) of a migrant PCA wanting more paid hours. Other factors most strongly associated with underemployment for migrant PCAs included being on a casual contract (OR 2.18), working in a for-profit employer (OR 1.82) and holding a post-school qualification (especially a degree - OR 2.20). 


\section{Discussion}

Our analysis points to some significant differences between migrant HCWs and PCAs and their Australian-born counterparts in respect of the two key dimensions of poor job quality we investigated. Secure contract status and having sufficient hours of work are crucial to economic security for workers and in aged care, more specifically, better quality jobs are related to lower rates of employee turnover and improved employee well-being (Burgess et al. 2018).

There are significant differences between ESB and NESB workers within each occupation in respect of exposure to casual status and underemployment. This finding resonates with earlier studies that suggest it is particular groups of migrants - those who are the most 'different' from the local norm - who are most likely to experience such disadvantage (Doyle and Timonen 2009; Stevens, Hussein and Manthorpe 2012; Jönson and Giertz 2013). What is distinctive about our findings here, however, is that the migrant aged care workers in Australia are overwhelmingly permanent residents, rather than temporary migrants as is the case in many of the European studies above. Nevertheless, it is striking that in our study, being on a temporary visa, was associated for PCAs with being casually employed and for HCWs with underemployment, which points to the additional layer of vulnerability that temporary migrants experience (Howe and Owens 2016).

\section{Casual status}

ESB PCAs and, to a greater degree, NESB HCWs were significantly more likely to be on a casual contract than other groups. Our findings contrast with the Swedish study outlined above that found that while non-Nordic migrant care workers, including both home care and residential workers, were more likely to be in temporary employment than native or Nordic migrants, these effects disappeared after controlling for variables such as gender, age, education and years in the occupation (Jönson and Giertz 2013: 816). Unlike this Swedish study, in our study these effects remained even after controlling for such characteristics.

Casual status in Australia, as in most countries, carries with it a range of disadvantages for workers, 
linked both to pay insecurity and to working time insecurity (Campbell and Burgess 2018;

Campbell et al. 2019). The consequences, however, of casual employment are different for HCWs and PCAs. As Fudge argues, the institutional setting in which work is performed shapes both the nature and the scope of labour regulation (2012: 17). The location of the work undertaken by HCWs in clients' homes makes it very different from the institutional workplaces around which labour regulation and its enforcement have been built, including in residential aged care (Charlesworth 2017: 143). The funding and organisation of work carried out in these two different locations also means that casual HCWs are far more likely to have short and episodic hours of work built around individual client visits, while casual PCAs in institutional settings are more likely to have shifts of several consecutive hours. The relatively predicable organisation of working time in institutional workplaces provide the basis for more working time and pay security than is the case for HCWs (Charlesworth 2017: 143-144).

\section{Underemployment}

We found that NESB HCWs and PCAs were significantly more likely than their Australian-born or ESB counterparts to want more hours of work in their current job than they currently had. This strong association may also be due to the relative lack of family networks and other economic supports for more recently arrived NESB migrants, particularly women (Ressia, Strahan and Bailey 2017) and the fact that the process of upward mobility takes longer for 'visible' skilled women migrants than for 'non-visible' skilled women (Webb 2015: 42). Wanting more hours of work in the current job is a significant driver for holding a second job (Bamberry and Campbell 2012) and in the case of aged care may also reflect relatively low rates of pay which combined with the lack of longer hour part-time or full-time work - is particularly difficult for migrants without family and economic capital.

\section{Time spent in Australia}

One of the key issues we explored in this study is the extent to which increased exposure to casual status and underemployment decreased with time spent in Australia. The literature suggests that time spent in a host country has a mitigating effect on employment disadvantage (Demireva 2011; 
Correa-Velez, Barnett and Gifford 2015). For example, a European study (Peracchi and Depalo

2006) found that while initially migrants, particularly female migrants, had lower employment rates than locally born workers, these differences progressively diminished over time, particularly for non-EU migrants. Our analysis supports the general trend of such findings as generally time in Australia reduced the likelihood of being on a casual contract for migrant workers.

Some differences were identified depending on country of birth. NESB HCWs when compared to their ESB peers were less likely to be on a casual contract with each year in Australia. However, for NESB PCAs the likelihood of being on a casual contact actually increased with each year spent in Australia. The differences in employer practice in the two sectors may provide at least a partial explanation. Typically, home care employers start workers off on casual contracts and are most likely to offer part-time status to workers who are willing to work additional hours which the comparatively higher underemployment of NESB HCWs suggests may be the case. In the residential care sector where PCAs generally have a lower rate of casual employment, NESB PCAs have both a shorter tenure with their employer and are more likely to hold a second job than ESB PCAs, which may mean casual workers may not be offered or available for regular part-time work.

In terms of underemployment we found that for migrant HCWs the effect of time in terms of years in Australia was paradoxical. With each year in Australia migrant HCWs were more likely to be underemployed (although compared to EBS workers, NESB HCWs experienced lower odds of underemployment with more time in Australia). In contrast, migrant PCAs were less likely to be underemployed with increasing time spent in Australia, with no difference observed between ESB and NESB migrants. This may be because the institutional location of residential aged care provides more opportunities to access additional hours for workers with longer tenure, whether through increased regular hours of work or being able to access additional shifts when other staff are absent. 


\section{Further factors influencing the employment conditions of migrant workers}

Consistent with the poorer job quality faced by migrant social care workers in for-profit employers in the UK (Hussein and Manthorpe 2014; Hussein 2017), we found that for-profit employment was associated with a higher likelihood of being on a casual contract and underemployment for NESB migrants, particularly HCWs. While much lower than in the UK (Marczak and Wistow 2016), forprofit employment in Australia is increasing in both sectors, particularly when measured by numbers of clients or numbers of beds rather than size of organisation as in Table 2. In 2017/18, 17 per cent of home care packages and 47 per cent of residential care places were delivered by forprofit providers (Australian Department of Health 2018). Given our findings, a rise in casualisation with associated underemployment may well result for migrant frontline aged care workers with further projected increases in for-profit employment (Davidson 2018).

In addition we found that for migrant PCAs the likelihood of underemployment increased with holding post school qualifications. Why this might be the case is not entirely clear. Australian studies focused on those with permanent migrant status suggest that women with high levels of education may end up in care work because of perceived language difficulties, the lack of recognition of overseas qualifications, as well as wanting work that accommodates family responsibilities in a context where few other supportive networks exist (O’Dwyer and ColicPeisker 2017; Hamilton et al. 2019). At the same time the lack of such networks and of economic resources can make migrant aged care workers more dependent on obtaining sufficient hours of paid work to meet financial obligations.

\section{Conclusion}

Our study is important for two main reasons. Migrants and particularly NESB migrants are a growing proportion of the Australian frontline aged care workforce, and in their direct engagement with aged care recipients make a substantial contribution to the quality of aged care services, as in other countries (Walsh and Shutes 2013). Thus, the extent to which job and working time insecurity are more prevalent for migrant aged care workers risks undermining not only the well- 
being of migrant workers but also that of the older people with whom they work (Walsh and Shutes 2013: 414).

Both casual status and underemployment have a material effect on low-paid workers in terms of having access to sufficient predictable income and also to on the job training, which is crucial in gaining any career progression (Chalmers, Campbell and Charlesworth 2005: 51). For migrant workers such effects are exacerbated by the precarity inherent in the migrant experience, particularly for newer migrants and those on temporary visas (Howe and Owens 2016). Recent shifts in migration policy have emphasised temporary over permanent migration and have made it more difficult for those on temporary visas to transition to permanency, especially for those assessed as 'low skilled' such as frontline care workers (Howe, Charlesworth and Brennan 2019). A 2016 ABS survey of recent Australian migrants shows that frontline care workers who had arrived in the last five years were far more likely to be on temporary visas than those who had arrived a decade before. Moreover, migrant care workers born in India, the Philippines, Nepal, Sri Lanka and Bangladesh were three times as likely to enter on a temporary visa compared to care workers born in other countries (Eastman et al. 2018a).

Our analysis shows that despite having access to the same formal minimum labour standards as other locally born and ESB migrants, NESB frontline aged care workers are more likely to be exposed to two key dimensions of poor job quality in casual status and underemployment. This suggests that there may be well be 'racialised hierarchies' in access to better or worse conditions in care work in Australia as elsewhere (Walsh and Shutes 2012: 396). Relying on highly qualified migrants to undertake undervalued and relatively poorly paid work, may also negatively impact on migrant worker well-being and ultimately care quality (NgochaChaderopa and Boon 2016: 42).

Further, the poorer outcomes documented in our study for migrant workers located in for-profit employers and for those on temporary visas may well be exacerbated with the increased marketisation of aged care in Australia and the policy shift towards 'permanent' temporary 
migration (Mares 2016). The growing proportion of recent migrants in the frontline aged care work thus has implications not only for quality of the jobs held by frontline aged care migrant workers but also for the quality of services. The relatively poorer conditions experienced by migrant aged care workers, particularly those born in NESB countries, works not only to normalise inadequate conditions of work in the sector but also undercuts good quality relationship-based care through increased staff turnover and poor continuity of care. Discontent with hours and shifts and with pay are two key reasons HCWs and PCAs cite for leaving their last aged care employer (Mavromaras et al. 2017: 35, 94).

Despite the projected demand for an increased number of workers in aged care (Productivity Commission 2011; Department of Health 2018), employers in the sector have exhibited a strong preference to employ individual workers for less than full-time hours. Over recent years there has also been employer lobbying for migrant workers to meet the demand for aged care workers, not currently filled by local workers (Adamson et al. 2017). The persistence and extent of underemployment in aged care is perplexing and points to the need for strategies that would enhance attraction and retention through improvements in the wages and working conditions of all aged care workers regardless of whether they are Australian-born or a permanent or temporary migrant (Howe, Charlesworth and Brennan 2019: 241).

There are two possible limitations to our analysis. Firstly, NESB migrant frontline aged care workers are not a homogenous group. While our paper does not analyse the intra-group differences between NESB migrants, such an analysis is a crucial one to take up in further research. A study drawing on the 2012 NACWCS data found distinct differences between Asian PCAs, with increased precarity for those from Southern Asia, for whom casual work and underemployment were higher (Isherwood and King 2017: 2003). In further research, it may be useful to examine intragroup differences between NESB HCWs as well as the extent to which disadvantage washes out over time for NESB workers from diverse birthplaces. Surprisingly in Australia there is little qualitative work on migrant aged care workers. One recent Australian study found that many educated migrant women working in frontline care work found this work 
both 'meaningful' and 'accessible', notwithstanding the wider context of gendered and racialised discourses about migrant women being 'well suited' to the care sector (Hamilton et al. 2019:

16). Further qualitative research specifically investigating the employment experiences of migrant aged care workers is also warranted. This would provide an important perspective on the findings in this paper, drawing out diverse lived experiences of NESB migrant worker disadvantage in Australian aged care employment.

\section{Statement of Funding}

\section{Statement of Ethical Approval}

Ethical approval for the 2016 NACWCS was granted by the Flinders University Human Research Ethics Committee.

\section{References}

Adamson E, Cortis N, Brennan D and Charlesworth S (2017) Social care and migration policy in Australia: Emerging intersections? Australian Journal of Social Issues 52, 78-94.

Armstrong P (2016) 'Conclusion: Where do we go from here'. In Baines D and Armstrong P (eds) Promising Practices in Long Term Care: Ideas Worth sharing Canadian Centre for Policy Alternatives, Montréal.

Australian Bureau of Statistics [ABS] (2018a) Characteristics of Employment Australia, August 2018, Cat No 6333.0.

Australian Bureau of Statistics [ABS] (2018b) Labour Force Australia, September 2018 Cat. No. 6202.0

Australian Department of Health (2018) 2017-18 Report on the Operation of the Aged Care Act 1997, Commonwealth of Australia, Canberra.

Bamberry L and Campbell 1 (2012) Multiple job holders in Australia: motives and personal impact. Australian bulletin of labour 38, 293-314.

Bauer G and Österle A (2013) Migrant care labour: The commodification and redistribution of 
care and emotional work. Social Policy and Society 12, 461-473.

Boese M, Campbell I, Roberts W.and Tham JC (2013) Temporary migrant nurses in Australia: Sites and sources of precariousness. The Economic and Labour Relations Review 24, $316-$ 339.

Michel S and Peng I (eds) (2017) Gender, migration, and the work of care. Palgrave Macmillan, Cham.

Burchell B, Sehnbruch K, Piasna A and Agloni N (2014) The quality of employment and decent work: definitions, methodologies, and ongoing debates. Cambridge journal of economics $\mathbf{3 8}$, 459-477.

Burgess J, Connell J, Nankervis A, Dhakal S and Fitzgerald S (2018) Developing sustainable career pathways for aged care workers: A WA case study. Bankwest Curtin Economic Centre, Perth.

Campbell I and Burgess J (2018) Patchy progress? Two decades of research on precariousness and precarious work in Australia. Labour \& Industry: a journal of the social and economic relations of work $\mathbf{2 8}, 48-67$.

Campbell I, Macdonald F and Charlesworth S (2019) On-Demand Work in Australia. In O’Sullivan M. et al. (eds) Zero-Hours and On-Call Work in Anglo-Saxon Countries, Springer Press, Berlin, 67-90.

Chalmers J, Campbell I and Charlesworth S (2005) Part-time work and caring responsibilities in Australia: Towards an assessment of job quality. Labour \& Industry: a journal of the social and economic relations of work 15, 41-66.

Chalmers J and Campbell I (2008) Job quality and part-time work in the retail industry: an Australian case study. The International Journal of Human Resource Management 19, 487500.

Charlesworth S (2017) Partial protection? The regulation of home care workers' working conditions. In Fenwick F and Van Goethem V (eds) Regulating for Equitable and Job-Rich Growth Edward Elgar Publishing, 125-150. 
Charlesworth S, Welsh J, Strazdins L, Baird M and Campbell I (2014) Measuring poor job quality amongst employees: the VicWAL job quality index. Labour \& Industry 24, 103-123.

Cassells R, Duncan AS, Mavisakalyan A, Phillimore J, Seymour R and Tarverdi Y (2018) Future of Work in Australia: Preparing for tomorrow's world Curtin Business School, Perth.

Colic-Peisker V (2011) 'Ethnics' and 'Anglos' in the Labour Force: Advancing Australia Fair? Journal of Intercultural Studies 32, 637-654.

Colombo F, Llena-Nozal A, Mercier J and Tjadens F (2011) Help Wanted?: Providing and Paying for Long-Term Care, OECD Health Policy Studies, OECD Publishing, Paris.

Correa-Velez I, Barnett AG and Gifford S (2015) Working for a better life: Longitudinal evidence on the predictors of employment among recently arrived refugee migrant men living in Australia. International Migration 53, 321-337.

Davidson B (2018) 'The Marketisation of Aged Care in Australia' in Cahill D and Toner P (eds) Wrong Way: How Privatisation and Economic Reform Backfired, LaTrobe University Press, Bundoora.

Demireva N (2011) New migrants in the UK: employment patterns and occupational attainment. Journal of Ethnic and Migration Studies 37, 637-655.

Department of Health (2018) A Matter of Care Australia's Aged Care Workforce Strategy, Commonwealth of Australia, Canberra. Available online at: https://agedcare.health.gov.au/sites/default/files/documents/09_2018/aged_care_workforce_stra tegy_report.pdf [Accessed 30 September 2018].

Doyle M and Timonen V (2009) The different faces of care work: understanding the experiences of the multi-cultural care workforce. Ageing \& Society 29, 337-350.

Eastman C, Charlesworth S and Hill E (2018a) Fact Sheet 1: Migrants in Frontline Care Markets Migration \& the Work of Care, Social Policy Research Centre, UNSW. Available at: https://www.sprc.unsw.edu.au/media/SPRCFile/Migrants_in_Frontline_Care_Final.pdf 
[Accessed 10 November 2018].

Eastman C, Charlesworth S and Hill E (2018b) Fact Sheet 3: Aged and Disabled Carers Markets

Migration \& the Work of Care, Social Policy Research Centre, UNSW. Available at:

https://www.sprc.unsw.edu.au/media/SPRCFile/Aged_and_Disabled_Carers_Final.pdf

[Accessed 10 November 2018].

Eastman C, Charlesworth S and Hill E (2018c) Fact Sheet 4: Personal Care Assistants Markets

Migration \& the Work of Care, Social Policy Research Centre, UNSW. Available at:

https://www.sprc.unsw.edu.au/media/SPRCFile/Personal_Care_Assistants_Final.pdf

[Accessed 10 November 2018].

European Foundation for the Improvement of Living and Working Conditions [Eurofound] (2007)

Employment and working conditions of migrant workers, Eurofound, Dublin.

Fudge J (2012) Blurring legal boundaries: Regulating for decent work. Challenging the legal boundaries of work regulation. In Fudge J and McCrystal SK (eds) Challenging the Legal Boundaries of Work Regulation Hart Publishing, Oxford.

Green F (2009) Demanding Work: The Paradox of Job Quality in the Affluent Economy, Princeton University Press.

Hamilton M, Hill E and Adamson E (2019) A ‘career shift? Bounded agency in migrant employment pathways in the aged care and early childhood education and care sectors in Australia Journal of Ethnic and Migration Studies, DOI: 10.1080/1369183X.2019.1684246

Ho C and Alcorso C (2004) Migrants and Employment Challenging the success story Journal of Sociology 40, 237-259.

Howe AL (2009) Migrant care workers or migrants working in long-term care? A review of Australian experience. Journal of Aging \& Social Policy 21, 374-392

Howe J, Charlesworth S and Brennan D (2019) Migration Pathways for Frontline Care Workers in Australia and New Zealand: Front Doors, Side Doors, Back Doors and Trapdoors University of NSW Law Journal 42, 211-241. 
Howe J and Owens R (2016) Temporary Labour Migration in the Global Era: The Regulatory Challenges Bloomsbury Publishing, London.

Hussein S (2017) 'We don't do it for the money'... The scale and reasons of poverty-pay among frontline long-term care workers in England. Health \& social care in the community 25, $1817-1826$.

Hussein S and Malthorpe J (2014) Structural marginalisation among the long-term care workforce in England: evidence from mixed-effect models of national pay data Ageing \& Society 34, 21-41.

Isherwood L and King D (2017) Targeting workforce strategies: understanding intra-group differences between Asian migrants in the Australian aged care workforce. International Journal of Care and Caring 1, 191-207.

Jönson H and Giertz A (2013) Migrant care workers in Swedish elderly and disability care: are they disadvantaged? Journal of Ethnic and Migration Studies 39, 809-825.

Mares P (2016) Not quite Australian: How temporary migration is changing the nation. Text Publishing, Melbourne.

Marczak J and Wistow G (2016) Commissioning long-term care services. In Gori, C. Jose-Luis Fernandez, J-L. and Wittenberg, R. (eds) Long-Term Care Reforms in OECD Countries Bristol University Press, Bristol, 117-142.

Mavromaras K, Knight G, Isherwood L, Crettenden A, Flavel J, Karmel T, Moskos M, Smith L, Walton H and Wei Z (2017) The Aged Care Workforce 2016, Department of Health, Canberra.

Meagher G, Cortis N, Charlesworth S and Taylor W (2019) Meeting the social and emotional support needs of older people using aged care services, Social Policy Research Centre, Sydney.

Ngocha-Chaderopa NE and Boon B (2016) Managing for quality aged residential care with a migrant workforce. Journal of Management \& Organization 22, 32-48. 
Noack A and Vosko L (2011) Precarious Jobs in Ontario: Mapping Dimensions of Labour Market Insecurity by Workers' Social Location and Context. Report prepared for the Ontario Law Commission, Vulnerable Worker Project. Ontario Law Commission, Toronto.

O'Dwyer M and Colic-Peisker V (2016) Facilitating the professional transition of migrants in Australia: does gender matter? Australian Journal of Social Issues 51, 47-66.

OECD (2019) Health at a Glance 2019: OECD Indicators OECD, Paris.

Peracchi F and Depalo D (2006) Labor market outcomes of natives and immigrants: Evidence from the ECHP for the World Bank. University of Rome Tor Vergata. Available at: http://siteresources.worldbank.org/SOCIALPROTECTION/Resources/SP-Discussionpapers/Labor-Market-DP/0615.pdf [Accessed 20 June 2018].

Pollaers J (2018) A Matter of Care Australia's Aged Care Workforce Strategy, Aged Care Workforce Strategy Taskforce. Commonwealth of Australia.

Productivity Commission (2011) Caring for Older Australians Report No. 53, Final Inquiry Report, Canberra.

Ressia S, Strachan G and Bailey J (2017) Operationalizing intersectionality: An approach to uncovering the complexity of the migrant job search in Australia. Gender, Work \& Organization 24, 376-397.

Senate Community Affairs Reference Committee (2017) Future of Australia's aged care sector workforce. Commonwealth of Australia

Shutes I and Chiatti C (2012) Migrant labour and the marketisation of care for older people: The employment of migrant care workers by families and service providers Journal of European social policy 22, 392-405.

Simonazzi A (2009) Care regimes and national employment models. Cambridge Journal of Economics 33, 211-232.

Stevens M, Hussein S and Manthorpe J (2012) Experiences of Racism and Discrimination among Migrant Care Workers in England: Findings from a Mixed-methods Research Project. Ethnic and 
Racial Studies 35, 259-80.

Tune D (2017) Legislated Review of Aged Care 2017 Department of Health, Commonwealth of Australia.

Van Hooren F (2012) Varieties of Migrant Care Work: Comparing patterns of migrant labour in social care Journal of European Social Policy 22, 133-147.

Vosko LF, MacDonald M and Campbell I (eds) (2009) Gender and the contours of precarious employment. Routledge.

Walsh K and Shutes I (2013) Care relationships, quality of care and migrant workers caring for older people. Ageing \& Society 33, 393-420.

Webb S (2015) The feminisation of migration and the migrants VET policy neglects: the case of skilled women secondary migrants in Australia. Journal of Vocational Education \& Training 67, 26-46.

Wilkins R and Lass I (2018) The Household, Income and Labour Dynamics in Australia Survey: Selected Findings from Waves 1 to 16. Melbourne Institute: Applied Economic \& Social Research. University of Melbourne.

Williams F (2012). Converging variations in migrant care work in Europe. Journal of European Social Policy 22, 363-376. 

Table 1: Frontline care occupations by birthplace and sex

\begin{tabular}{|c|c|c|c|c|c|c|c|c|c|c|c|c|}
\hline Birthplace & \multicolumn{4}{|c|}{ Overseas-born } & \multicolumn{3}{|c|}{ Australian-born } & \multicolumn{5}{|c|}{ Total } \\
\hline Occupation & $\begin{array}{c}\text { Female } \\
\%\end{array}$ & $\begin{array}{c}\text { Male } \\
\%\end{array}$ & $\begin{array}{c}\text { Total } \\
\#\end{array}$ & $\begin{array}{c}\text { Total } \\
\text { NESB }\end{array}$ & $\begin{array}{c}\text { Female } \\
\%\end{array}$ & $\begin{array}{c}\text { Male } \\
\%\end{array}$ & $\begin{array}{c}\text { Total } \\
\#\end{array}$ & $\begin{array}{c}\text { Female } \\
\%\end{array}$ & $\begin{array}{c}\text { Male } \\
\%\end{array}$ & $\begin{array}{c}\text { Total } \\
\#\end{array}$ & $\begin{array}{c}\text { Total } \\
\text { overseas- } \\
\text { born } \%\end{array}$ & $\begin{array}{c}\text { Total } \\
\text { NESB } \\
\%\end{array}$ \\
\hline $\begin{array}{l}\text { Aged \& } \\
\text { Disabled } \\
\text { Carers }\end{array}$ & $76.2 \%$ & $23.8 \%$ & 47,813 & 34,112 & $82.1 \%$ & $17.9 \%$ & 81,537 & $80.0 \%$ & $20.0 \%$ & 129,346 & $37.0 \%$ & $26.4 \%$ \\
\hline
\end{tabular}

Source: ABS Census $2016^{1}$

${ }^{1}$ Census data for this six-digit occupational grouping is not publicly available and was purchased by the authors from the ABS. 
Table 2: Comparison of socio-demographic and occupational characteristics by country of birth: HCWs and PCAs

\begin{tabular}{|c|c|c|c|c|c|c|}
\hline & \multicolumn{3}{|l|}{$\begin{array}{l}\text { HCWs } \\
(\mathrm{n}=4,355)\end{array}$} & \multicolumn{3}{|l|}{$\begin{array}{l}\text { PCAs } \\
(\mathrm{n}=2,759)\end{array}$} \\
\hline & $\begin{array}{l}\text { Australian } \\
(70.3 \%)\end{array}$ & $\begin{array}{l}\text { ESB } \\
(11.3 \%)\end{array}$ & $\begin{array}{l}\text { NESB } \\
(18.4 \%)\end{array}$ & $\begin{array}{l}\text { Australian } \\
(60.0 \%)\end{array}$ & $\begin{array}{l}\text { ESB } \\
(8.3 \%)\end{array}$ & $\begin{array}{l}\text { NESB } \\
(31.7 \%)\end{array}$ \\
\hline Female $^{\mathrm{a}}$ & 91.2 & $89.3 * * *$ & $87.2 * * *$ & 90.2 & $91.8 * * *$ & $80.3 * * *$ \\
\hline Age (mean, years) ${ }^{\mathrm{a}}$ & 50.36 & $52.77 * * *$ & $49.15 * * *$ & 45.39 & $48.51 * * *$ & $40.88 * * *$ \\
\hline $\begin{array}{l}\text { Financial } \\
\text { dependants }{ }^{\text {a }} \text { Partner } \\
\text { and children Partner } \\
\text { only } \\
\text { Children only } \\
\text { Others } \\
\text { None }\end{array}$ & $\begin{array}{l}16.1 \\
14.4 \\
18.7 \\
0.8 \\
50.0\end{array}$ & $\begin{array}{l}18.3 * * * \\
9.8 * * * \\
15.6 * * * \\
0.1 * * * \\
56.2 * * *\end{array}$ & $\begin{array}{l}17.9 * * * \\
9.7 * * * \\
29.1 * * * \\
1.6 * * * \\
41.8 * * *\end{array}$ & $\begin{array}{l}19.2 \\
12.6 \\
14.7 \\
0.8 \\
52.7\end{array}$ & $\begin{array}{l}15.7^{* * *} \\
14.5^{* * *} \\
14.5 \\
0.6^{*} \\
54.8^{* *}\end{array}$ & $\begin{array}{l}22.3 * * * \\
15.2 * * * \\
21.1 * * * \\
2.7 * * * \\
38.7 * * *\end{array}$ \\
\hline $\begin{array}{l}\text { Years in Australia } \\
(\text { mean })^{\mathrm{b}}\end{array}$ & - & 28.83 & $24.30 * * *$ & - & 26.44 & $13.49 * * *$ \\
\hline $\begin{array}{l}\text { Residency } \\
\text { status }^{b} \\
\text { Permanent } \\
\text { Temporary }\end{array}$ & - & $\begin{array}{l}99.3 \\
0.7\end{array}$ & $\begin{array}{l}94.2 * * * \\
5.8 * * *\end{array}$ & $\begin{array}{l}- \\
-\end{array}$ & $\begin{array}{l}97.6 \\
2.4\end{array}$ & $\begin{array}{l}86.9 * * * \\
13.1 * * *\end{array}$ \\
\hline $\begin{array}{l}\text { Highest post-school } \\
\text { qualification }^{\mathrm{a}} \\
\text { None } \\
\text { Certificate } \\
\text { Diploma } \\
\text { Degree }\end{array}$ & $\begin{array}{l}16.3 \\
65.4 \\
11.5 \\
6.8\end{array}$ & $\begin{array}{l}11.9^{* * * *} \\
62.2^{* * *} \\
12.4^{*} \\
13.5^{* * *}\end{array}$ & $\begin{array}{l}10.0^{* * * *} \\
44.9^{* * *} \\
15.8^{* * * *} \\
29.2 * * *\end{array}$ & $\begin{array}{l}13.8 \\
78.6 \\
4.5 \\
3.1\end{array}$ & $\begin{array}{l}11.9^{* * *} \\
76.6^{* * *} \\
7.2^{* * *} \\
4.4^{* * *}\end{array}$ & $\begin{array}{l}12.3^{* * *} \\
52.0^{* * *} \\
8.8^{* * *} \\
26.9^{* * *}\end{array}$ \\
\hline $\begin{array}{l}\text { Employment } \\
\text { contract }^{\mathrm{a}} \\
\text { Permanent/fixed term } \\
\text { Casual }\end{array}$ & $\begin{array}{l}75.0 \\
25.0\end{array}$ & $\begin{array}{l}74.9 \\
25.1\end{array}$ & $\begin{array}{l}70.0 * * * \\
30.0 * * *\end{array}$ & $\begin{array}{l}90.4 \\
9.6\end{array}$ & $\begin{array}{l}88.9^{* * *} * \\
11.1^{* * *}\end{array}$ & $\begin{array}{l}90.2 \\
9.8\end{array}$ \\
\hline Part-time $(<38 \text { hours })^{\mathrm{a}}$ & 84.5 & $85.6 * *$ & $89.1 * * *$ & 78.8 & $82.2 * * *$ & $80.4 * * *$ \\
\hline $\begin{array}{l}\text { Paid hours worked per } \\
\text { week (mean) }^{\mathrm{a}}\end{array}$ & 25.01 & 24.84 & $23.97 * * *$ & 30.72 & $31.28 * *$ & $31.31 * * *$ \\
\hline $\begin{array}{l}\text { Preferred } \\
\text { hours }{ }^{\mathrm{a}} \text { More } \\
\text { hours Less } \\
\text { hours Same } \\
\text { hours }\end{array}$ & $\begin{array}{l}43.6 \\
11.4 \\
45.0\end{array}$ & $\begin{array}{l}45.1 * \\
7.6 * * * \\
47.2 * * *\end{array}$ & $\begin{array}{l}55.7 * * * \\
9.5 * * * \\
34.8 * * *\end{array}$ & $\begin{array}{l}33.6 \\
10.3 \\
56.0\end{array}$ & $\begin{array}{l}27.8 * * * \\
7.3 * * * \\
64.9 * * *\end{array}$ & $\begin{array}{l}49.6 * * * \\
3.8 * * * \\
46.6 * * *\end{array}$ \\
\hline More than one job ${ }^{a}$ & 15.6 & $11.6^{* * *}$ & $21.0 * * *$ & 6.7 & $5.9 * *$ & $13.4 * * *$ \\
\hline $\begin{array}{l}\text { Years in organisation } \\
(\text { mean })^{a}\end{array}$ & 6.41 & $6.01 * * *$ & $5.83 * * *$ & 6.78 & $6.35 * * *$ & $5.82 * * *$ \\
\hline $\begin{array}{l}\text { Type of } \\
\text { employera Not for } \\
\text { profit } \\
\text { For profit } \\
\text { Government }\end{array}$ & $\begin{array}{l}68.8 \\
11.2 \\
20.0\end{array}$ & $\begin{array}{l}77.7 * * * \\
6.1 * * * \\
16.2 * * *\end{array}$ & $\begin{array}{l}75.6^{* * *} \\
8.4^{* * *} \\
16.0 * * *\end{array}$ & $\begin{array}{l}64.8 \\
30.0 \\
5.2\end{array}$ & $\begin{array}{l}54.8 * * * \\
39.9 * * * \\
5.3\end{array}$ & $\begin{array}{l}59.9 * * * \\
38.9 * * * \\
1.3 * * *\end{array}$ \\
\hline $\begin{array}{l}\text { Size of } \\
\text { organisation }{ }^{\text {a Small }} \\
(20 \text { or less) Medium } \\
(21-50) \\
\text { Large }(51-100) \\
\text { Very large (more than } \\
100)\end{array}$ & $\begin{array}{l}21.1 \\
19.8 \\
23.3 \\
35.7\end{array}$ & $\begin{array}{l}17.7 * * * \\
16.5 * * * \\
32.1 * * * \\
33.7 * *\end{array}$ & $\begin{array}{l}16.7 * * * \\
16.4 * * * \\
25.0 * * \\
41.8 * * *\end{array}$ & $\begin{array}{l}1.3 \\
10.7 \\
31.9 \\
56.1\end{array}$ & $\begin{array}{l}1.7 * \\
12.2 * * * \\
29.4 * * * \\
56.7\end{array}$ & $\begin{array}{l}0.6 * * * \\
8.9 * * * \\
36.0 * * * \\
54.5 * * *\end{array}$ \\
\hline
\end{tabular}

Notes: a Australia is the reference category. ${ }^{b_{E S B}}$ is the reference category.

$* \mathrm{p}<.05, * * \mathrm{p}<.01, * * * \mathrm{p}<.001$ 

Table 3: Casual employment: HCWs and PCAs

\begin{tabular}{|c|c|c|c|c|c|c|c|c|c|c|c|c|}
\hline & \multicolumn{6}{|c|}{ HCWs } & \multicolumn{6}{|c|}{ PCAs } \\
\hline & \multicolumn{3}{|c|}{ All } & \multicolumn{3}{|c|}{ Migrants } & \multicolumn{3}{|c|}{ All } & \multicolumn{3}{|c|}{ Migrants } \\
\hline & OR & & $\mathrm{CI}$ & OR & $95 \%$ & ${ }_{0 \mathrm{CI}}$ & $\mathrm{OR}$ & & $\mathrm{CI}$ & OR & & $\mathrm{CI}$ \\
\hline Constant & $1.78^{* * *}$ & - & & $0.14^{* * * *}$ & - & & $0.69^{*}$ & - & & $5.60^{* * *}$ & - & \\
\hline $\begin{array}{l}\text { Country of birth: } \\
\text { Australia } \\
\text { ESB } \\
\text { NESB }\end{array}$ & $\begin{array}{l}0 \\
1.00 \\
1.45^{* * *}\end{array}$ & $\begin{array}{l}- \\
0.91 \\
1.34\end{array}$ & $\begin{array}{l}1.11 \\
1.56\end{array}$ & $\begin{array}{l}- \\
0 \\
5.09 * * *\end{array}$ & $\begin{array}{l}- \\
- \\
3.89\end{array}$ & 6.67 & $\begin{array}{l}0 \\
1.18^{* *} \\
0.70^{* * *}\end{array}$ & $\begin{array}{l}- \\
1.06 \\
0.65\end{array}$ & $\begin{array}{l}1.30 \\
0.75\end{array}$ & $\begin{array}{l}- \\
0 \\
0.40 * * *\end{array}$ & $\begin{array}{l}- \\
- \\
0.32\end{array}$ & 0.50 \\
\hline Years in Australia & - & - & & $0.99 *$ & 0.99 & 1.00 & - & - & & $0.98^{* * *}$ & 0.98 & 0.99 \\
\hline $\begin{array}{l}\text { NESB*Years in } \\
\text { Australia }\end{array}$ & - & - & & $0.96^{* * *}$ & 0.95 & 0.96 & - & - & & $1.02 * * *$ & 1.01 & 1.04 \\
\hline $\begin{array}{l}\text { Temporary } \\
\text { resident }\end{array}$ & - & - & & 1.26 & 0.89 & 1.79 & - & - & & $1.98 * * *$ & 1.70 & 2.31 \\
\hline Female & 0.91 & 0.82 & 1.01 & 1.04 & 0.87 & 1.25 & 0.99 & 0.91 & 1.07 & $1.80^{* * *}$ & 1.54 & 2.10 \\
\hline Age & $1.01^{* * *}$ & 1.01 & 1.01 & $1.06^{* * *}$ & 1.05 & 1.07 & $0.99 * * *$ & 0.99 & 1.00 & $0.98^{* * *}$ & 0.97 & 0.99 \\
\hline $\begin{array}{l}\text { Highest post- } \\
\text { school qual: } \\
\text { None } \\
\text { Certificate } \\
\text { Diploma } \\
\text { Degree }\end{array}$ & $\begin{array}{l}0 \\
1.03 \\
0.59^{* * *} \\
0.52^{* * *}\end{array}$ & $\begin{array}{l}- \\
0.95 \\
0.53 \\
0.46\end{array}$ & $\begin{array}{l}1.11 \\
0.67 \\
0.58\end{array}$ & $\begin{array}{l}0 \\
0.66^{* * *} \\
0.45^{* * *} \\
0.15^{* * *}\end{array}$ & $\begin{array}{l}- \\
0.55 \\
0.36 \\
0.11\end{array}$ & $\begin{array}{l}0.79 \\
0.56 \\
0.18\end{array}$ & $\begin{array}{l}0 \\
1.10^{*} \\
1.29^{* * *} \\
1.49^{* * *}\end{array}$ & $\begin{array}{l}- \\
1.01 \\
1.12 \\
1.33 \\
\end{array}$ & $\begin{array}{l}1.20 \\
1.47 \\
1.67\end{array}$ & $\begin{array}{l}0 \\
0.88 \\
0.67 * * \\
0.82\end{array}$ & $\begin{array}{l}- \\
0.71 \\
0.52 \\
0.66\end{array}$ & $\begin{array}{l}1.07 \\
0.87 \\
1.03\end{array}$ \\
\hline $\begin{array}{l}\text { Financial } \\
\text { dependents }\end{array}$ & $1.10^{* *}$ & 1.03 & 1.17 & $2.01 * * *$ & 1.77 & 2.28 & $0.62 * * *$ & 0.58 & 0.66 & $0.49 * * *$ & 0.43 & 0.55 \\
\hline Tenure in job & $0.92 * * *$ & 0.91 & 0.92 & $0.93^{* * *}$ & 0.91 & 0.94 & $0.76^{* * *}$ & 0.75 & 0.77 & $0.73 * * *$ & 0.71 & 0.76 \\
\hline Usual paid hours & $0.93^{* * * *}$ & 0.93 & 0.93 & $0.94^{* * * *}$ & 0.93 & 0.95 & $0.96^{* * *}$ & 0.96 & 0.96 & $0.92 * * *$ & 0.92 & 0.93 \\
\hline Prefer more hours & $1.39 * * *$ & 1.31 & 1.47 & 1.07 & 0.95 & 1.20 & $1.59 * * *$ & 1.50 & 1.69 & $1.95 * * *$ & 1.73 & 2.19 \\
\hline More than one job & $1.20^{* * *}$ & 1.11 & 1.29 & $1.32 * * *$ & 1.14 & 1.53 & $2.03 * * *$ & 1.87 & 2.21 & $2.41 * * *$ & 2.09 & 2.78 \\
\hline $\begin{array}{l}\text { Type of } \\
\text { employer: } \\
\text { Not-for-profit } \\
\text { For-profit } \\
\text { Government }\end{array}$ & $\begin{array}{l}0 \\
4.10^{* * *} \\
0.58 * * *\end{array}$ & $\begin{array}{l}- \\
3.76 \\
0.53 \\
\end{array}$ & $\begin{array}{l}4.46 \\
0.63\end{array}$ & $\begin{array}{l}0 \\
18.15^{* * *} \\
0.77^{* *}\end{array}$ & $\begin{array}{l}0 \\
14.70 \\
0.65\end{array}$ & $\begin{array}{c}22.41 \\
0.93\end{array}$ & $\begin{array}{l}0 \\
1.06 \\
2.67 * * *\end{array}$ & $\begin{array}{l}- \\
1.00 \\
2.31\end{array}$ & $\begin{array}{l}1.12 \\
3.08\end{array}$ & $\begin{array}{l}0 \\
1.19 * * \\
1.29\end{array}$ & $\begin{array}{l}0 \\
1.06 \\
0.73 \\
\end{array}$ & $\begin{array}{l}1.34 \\
2.29\end{array}$ \\
\hline $\begin{array}{l}\text { Size of agency: } \\
\text { Small } \\
\text { Medium } \\
\text { Large } \\
\text { Very large }\end{array}$ & $\begin{array}{l}0 \\
0.91^{*} \\
0.81^{* * *} \\
0.43^{* * *} \\
\end{array}$ & $\begin{array}{l}- \\
0.84 \\
0.75 \\
0.39 \\
\end{array}$ & $\begin{array}{l}1.00 \\
0.88 \\
0.46 \\
\end{array}$ & $\begin{array}{l}0 \\
0.76^{* *} \\
0.81^{* *} \\
0.32^{* * *} \\
\end{array}$ & $\begin{array}{l}- \\
0.63 \\
0.69 \\
0.27 \\
\end{array}$ & $\begin{array}{l}0.91 \\
0.95 \\
0.39 \\
\end{array}$ & $\begin{array}{l}0 \\
1.34 \\
1.47^{*} \\
1.50^{*} \\
\end{array}$ & $\begin{array}{l}- \\
0.97 \\
1.07 \\
1.09 \\
\end{array}$ & $\begin{array}{l}1.86 \\
2.01 \\
2.06 \\
\end{array}$ & $\begin{array}{l}0 \\
0.75 \\
1.03 \\
0.70 \\
\end{array}$ & $\begin{array}{l}- \\
0.43 \\
0.61 \\
0.41 \\
\end{array}$ & $\begin{array}{l}1.30 \\
1.75 \\
1.17 \\
\end{array}$ \\
\hline Nagelkerke $\mathrm{R}^{2}$ & .259 & & & .388 & & & .237 & & & .379 & & \\
\hline
\end{tabular}

Notes: $* \mathrm{p}<.05, * * \mathrm{p}<.01, * * * \mathrm{p}<.001$ 

Table 4: Underemployment: HCWs and PCAs

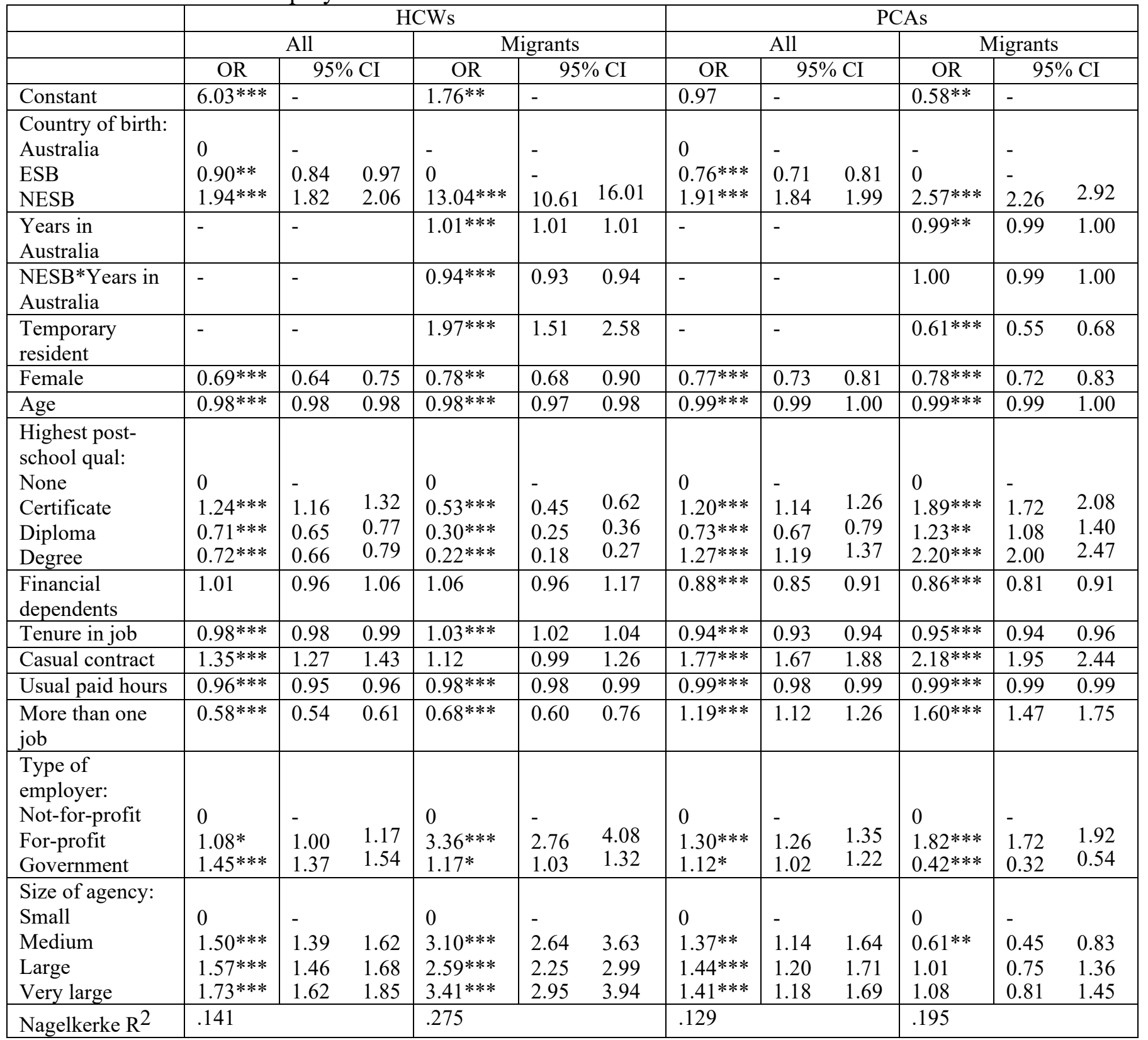

Notes: $* \mathrm{p}<.05, * * \mathrm{p}<.01, * * * \mathrm{p}<.001$ 